\title{
Pemanfaatan Media Sosial Dalam Pemasaran Sosial Bagi Remaja
}

\author{
Resti Sri Elwani, Firman Kurniawan
}

Biro Perencanaan, BKKBN, J1. Permata No.1, Halim Perdana Kusuma, Jakarta Timur, dan Departemen Ilmu Komunikasi, Fakultas Ilmu Sosial dan Ilmu Politik, Universitas Indonesia Gd. IASTH Lt. 6, Kampus UI Salemba, DKI Jakarta resti.srielwani@gmail.com,firmankurniawan@yahoo.com

\begin{abstract}
Adolescent face very vulnerable period of transition from childhood to adulthood. Because adolescents do not have enough knowledge and awareness to get through this transition, adolescents often experience various kinds of problems. Genereasi Berencana Program (GenRe) is one of the interventions to overcome this problem. The high intensity of adolescents in using social media is the foundation of the GenRe program choosing this new media as one of their communication channels. The use of social media is considered as a communication strategy that is relevant and appropriate for adolescents. This study aims to examine how social media is used in social marketing for adolescents and how create an effective message on social media to increase adolescent awareness. The research was conducted through a descriptive qualitative approach to explain how social media is used as a channel for social marketing communication and how to create effective message on social media. Three informans were selected based on purposive sampling technique. Data collection was carried out by interview and literature study. The data analysis technique used in this study refers to Miles \& Hubberman which consists of three subprocesses, namely data reduction, data presentation and drawing conclusions or verification. Social marketing theory is used for analysis to answer the problems in this study. The results showed that social media can be utilized as a social marketing communication channel for adolescent.But,low engagement of substance content compared to non-substance is a challenge faced by GenRe programs on social media. Frequency, consistency and involvement of influencers are some of the strategies that can be implemented to overcome these problems.
\end{abstract}

Keywords: adolescent awareness, social marketing, social media

\begin{abstract}
Abstrak
Remaja mengalami periode yang sangat rentan yaitu masa transisi dari masa anak-anak menuju masa dewasa. Karena remaja tidak memiliki pengetahuan dan kesadaran bagaimana melewati masa transisi ini mengakibatkan remaja seringkali mengalami berbagai macam masalah. Program Generasi Berencana (GenRe) adalah salah satu intervensi untuk mengatasi masalah tersebut. Tingginya intensitas remaja dalam mengakses media sosial menjadi landasan program GenRe memilih media baru tersebut sebagai salah satu saluran komunikasi mereka. Penggunaan media sosial dianggap sebagai strategi komunikasi yang relevan dan sesuai bagi remaja. Penelitian ini bertujuan untuk mengkaji bagaimana media sosial digunakan dalam pemasaran sosial bagi remaja dan bagaimana strategi pengemasan pesan yang efektif di media sosial untuk meningkatkan kesadaran remaja. Penelitian dilakukan melalui pendekatan kualitatif yang
\end{abstract}


bersifat deskriptif untuk menggali informasi secara mendalam dari narasumber agar mendapatkan penjelasan bagaimana media sosial digunakan sebagai saluran komunikasi pemasaran sosial bagi remaja dan bagaimana strategi pengemasan pesan yang efektif di media sosial. Tiga narasumber dalam penelitian ini dipilih berdasarkan teknik purposive sampling. Pengumpulan data dilakukan dengan wawancara dan studi literatur. Teknis analisis data yang digunakan dalam penelitian ini mengacu pada Miles \& Hubberman yang terdiri dari tiga subproses, yaitu reduksi data, penyajian data dan penarikan kesimpulan. Teori pemasaran sosial digunakan untuk analisis dan membantu menjawab permasalahan dalam penelitian ini. Hasil penelitian menunjukkan media sosial dapat dimanfaatkan sebagai saluran komunikasi pemasaran sosial bagi remaja. Namun media sosial tidak dapat berdiri sendiri sehingga pemilihan omni-channel adalah strategi yang lebih efektif. Rendahnya engagement konten substansi dibanding nonsubstansi adalah tantangan yang dihadapi pemasaran sosial program GenRe di media sosial. Frekuensi, konsistensi dan pelibatan influencer adalah beberapa strategi yang dapat diimplementasikan untuk mengatasi permasalahan tersebut.

Kata kunci: kesadaran remaja, media sosial, pemasaran sosial

\section{Pendahuluan}

Remaja menurut Peraturan Menteri Kesehatan RI Nomor 25 Tahun 2014 adalah penduduk dalam rentang usia 10-18 tahun (Kemenkes, 2014). Remaja, di dalam Bahasa Inggris disebut "adolescence" yang berasal dari kata kerja dalam bahasa Latin "adolescere", yang artinya "tumbuh menjadi dewasa". Oleh karena itu, masa remaja didefinisikan sebagai masa peralihan dari masa kanak-kanak ke masa dewasa yang ditandai dengan perubahan dan perkembangan fisik, kognitif, emosi, sosial dan perilaku (APA, 2002). Saat ini jumlah remaja di Indonesia berdasarkan hasil Susenas tahun 2018 adalah 63,82 juta jiwa, jumlah ini merupakan seperempat dari total penduduk Indonesia (BPS, 2018). Pada masa remaja Ini terjadi perubahan fisik, kognitif, sosial dan emosional pada diri seseorang. Menurut Hurlock (1998) masa transisi adalah faktor resiko utama timbulnya berbagai masalah dalam kehidupan remaja. Pada masa transisi ini remaja akan mengalami transisi secara emosional, sosialisasi, agama, hubungan keluarga dan moralitas. Perubahan yang terjadi ini memberikan dorongan kuat terhadap perilaku dan kehidupan remaja yang makin beragam dan pada ahirnya sangat berpotensi menimbulkan masalah bagi mereka. Menurut Stanhope dan Lancaster (2004) dalam (Nurhayati, 2011) beberapa permasalahan di kalangan remaja antara lain merokok, konsumsi alkohol, konsumsi obat terlarang, depresi atau keinginan bunuh diri, ketidakstabilan emosi, masalah fisik, masalah di sekolah dan perilaku seks beresiko.

Data WHO tahun 2020 menyebutkan setiap tahun ada 21 juta kasus kehamilan remaja yang terjadi di Negara-negara berkembang. Hal ini tidak mengherankan jika melihat hasil survey Demografi dan Kesehatan Indonesia (SDKI) tahun 2017 menyebutkan bahwa 2\% remaja wanita dan 8\% remaja pria mengaku telah melakukan hubungan seksual pranikah (BKKBN, 2017). Hubungan seksual pranikah pada remaja berakibat pada kehamilan yang tidak diinginkan yang kemudian menjadi penyebab utama terjadinya aborsi (WHO, 2014). Data Komnas Perlindungan Anak mengonfirmasi data tersebut dengan 
menyebutkan bahwa ternyata $21 \%$ remaja atau satu diantara lima remaja pernah melakukan aborsi (Ayu \& Kurniawati, 2017). Selanjutnya jumlah remaja yang telah menjadi perokok aktif adalah $55 \%$ pada remaja pria dan $1 \%$ dari remaja wanita. Sebagian besar dari mereka mengaku mulai merokok bahkan sebelum berumur 15 tahun. Setali tiga uang dengan jumlah remaja yang aktif mengonsumsi alkohol juga sangat tinggi yaitu $26 \%$ pada remaja wanita dan $39 \%$ pada remaja pria. Bahkan $49 \%$ dari mereka mengaku telah mengonsumsi alkohol sampai mabuk (BKKBN, 2017).

Beberapa keputusan spontan remaja yang dapat merusak kesehatan dan kesejahteraan mereka seperti ilustrasi kasus yang disebutkan sebelumnya adalah akibat kurangnya informasi bagaimana menghadapi masa transisi yang mereka alami. Sebagai contoh, dalam SDKI 2017 ditemukan bahwa remaja belum sepenuhnya memahami pentingnya kesehatan reproduksi. Dalam survey disebutkan hanya sekitar 50\% remaja yang mengetahui bahwa remaja wanita bisa hamil hanya setelah sekali melakukan hubungan seksual (BKKBN, 2017). Jika $50 \%$ lainnya tidak memahami hal itu, akibatnya tentu saja jumlah remaja yang melakukan hubungan seksual beresiko sebelum pernikahan masih tinggi sehingga kehamilan yang tidak diinginkan serta kasus aborsi juga terus terjadi. Beberapa penelitian menyebutkan bahwa untuk membantu remaja dalam menghadapi masa transisi adalah melalui pola komunikasi keluarga sebagai institusi yang terdekat dengan mereka (Nakhaee, Vagharseyyedin, Afkar, \& Mood, 2017). Namun penelitian lain menyebutkan bahwa edukasi yang disampaikan oleh pemerintah dapat meningkatkan pengetahuan dan kesadaran remaja untuk mengatasi beberapa masalah yang dihadapi ketika masa transisisi (Salam et al., 2016).

Salah satu strategi untuk melakukan edukasi bagi remaja dalam menghadapi masa transisi dapat dilakukan melalui pemasaran sosial. Pemasaran sosial adalah penggunaan prinsip-prinsip dan teknik-teknik pemasaran untuk memengaruhi target khalayak agar secara sukarela menerima, menolak, memodifikasi atau mengabaikan perilaku demi keuntungan individu, kelompok, atau masyarakat secara keseluruhan (Kotler \& Roberto, 1989). Pada dasarnya pemasaran sosial adalah strategi mengubah perilaku sosial dengan menggunakan prinsip-prinsip marketing konvensional dengan tujuan untuk meningkatkan penerimaan atas ide-ide sosial. Pemasaran sosial diakui sebagai strategi yang lebih efektif untuk menambah pengetahuan dan kesadaran masyarakat (French, 2012). Pemasaran sosial paling banyak digunakan untuk mengatasi masalah kesehatan masyarakat, seperti promosi perilaku sehat, pencegahan merokok, pengendalian penyakit, meningkatkan kesadaran pentingnya aktivitas fisik dan lain sebagainya (Dahl \& N, 2010). Pendekatan pemasaran konvensional yang diadopsi oleh pemasaran sosial untuk meningkatkan kesadaran masyarakat dalam menerapkan gaya hidup yang lebih sehat menjadi semakin diakui sebagai strategi yang lebih efektif untuk menambah pengetahuan dan kesadaran masyarakat (French, 2012). Kotler dan Roberto (1989) menyebutkan ada tiga sasaran pemasaran sosial yakni behaviour objectives, knowledge objectives dan belief objectives. Proses meningkatkan pemahaman dan kesadaran remaja dalam menghadapi masa transisi termasuk ke dalam kategori knowledge objectives. 
Salah satu konsep utama pemasaran sosial adalah pendekatan yang berorientasi pada khalayak, sehingga strategi komunikasi yang digunakan sebaiknya adalah yang paling sesuai dengan keseharian mereka (French, 2012). Di era maraknya teknologi internet seperti saat ini, dimana semua sudah serba digital dan online maka sangat mungkin melakukan pemasaran sosial melalui medium digital, media sosial. Apalagi jika melihat penetrasi internet di Indonesia saat ini, lebih dari 170 juta jiwa atau sekitar 64,8\% dari jumlah total penduduk Indonesia kini telah terhubung dengan internet (APJII, 2019). Data We Are Social (2019) melaporkan bahwa $92 \%$ pengguna internet di Indonesia berpartisipasi aktif dalam penggunaan media sosial. Bahkan jumlah waktu yang dialokasikan untuk mengakses media sosial juga mencapai 3 jam 26 menit per hari. Fenomena ini menunjukkan bahwa masyarakat Indonesia sangat menggemari media sosial.

Menurut Kaplan dan Haenlein (2010) media sosial adalah sekelompok aplikasi berbasis Internet yang dibangun di atas fondasi ideologis dan teknologi Web 2.0, dan yang memungkinkan pembuatan dan pertukaran Konten Buatan Pengguna (user generated content). Media sosial seperti Facebook, YouTube, Twiter, Path, Instagram merupakan salah satu platform media digital yang berperan dalam bertukar gagasan dan pendapat. Media sosial yang bersifat spreadability ini, secara teknis memberikan peluang bagi penggunanya untuk berbagi ragam konten secara independen (Kusumasari \& Arifianto, 2019). Jika dibandingkan dengan media tradisional, media sosial memungkinkan orang untuk secara aktif terlibat dalam proses komunikasi tidak hanya sebagai penerima informasi tetapi juga sebagai pembuat pesan. Oleh karena itu, Thackeray, Neiger dan Keller (2012) berpendapat strategi pemasaran sosial harus mengintegrasikan media sosial karena media ini memiliki potensi yang sangat potensial namun belum dimanfaatkan dengan optimal (Dotulong, 2019). Kent dan Taylor (1998) menyebutkan bahwa media sosial memiliki kemampuan untuk menjadi wadah terjadinya dialog diantara sesama penggunanya. Hubungan baik yang terjadi melalui dialog tersebut dapat mendorong pengguna media sosial untuk menjadi pendukung utama terjadinya perubahan sosial (Dotulong, 2019).

Para praktisi kampanye sosial dengan cepat mengenali potensi media sosial untuk menjangkau khalayak luas dalam kampanye pemasaran sosial. Media sosial dipandang memiliki kemampuan besar untuk mempengaruhi khalayak dalam artian positif. Dengan kata lain, para pemasar sosial melihat bahwa media sosial dapat digunakan untuk memberdayakan khalayak dalam membangun kesadaran bahkan perubahan perilaku (Thackeray et al., 2008 dalam Korda \& Itani, 2015). Pemasaran sosial melalui media digital, khususnya media sosial telah dilakukan oleh organisasi nirlaba dan beberapa lembaga Negara. Salah satu lembaga Negara yang menggunakan media sosial sebagai alat pemasaran sosial adalah BKKBN.

Badan Kependudukan dan Keluarga Berencana Nasional (BKKBN) adalah lembaga negara yang melaksanakan tugas pemerintahan bidang pengendalian penduduk dan penyelenggaraan keluarga berencana. Dalam pelaksanaan salah satu tugasnya, BKKBN fokus pada peningkatan pemahaman dan kesadaran remaja mengenai kesehatan reproduksi dan penyiapan kehidupan berkeluarga. Salah satu upaya BKKBN untuk meningkatkan kesadaran remaja adalah 
melakukan kampanye program Generasi Berencana (GenRe). Program ini bertujuan untuk membantu remaja agar memahami dan menyadari tentang pentingnya kesehatan reproduksi. Harapannya agar remaja terhindar dari tiga ancaman yang berkaitan dengan kesehatan reproduksi remaja, yaitu seks pra nikah, pernikahan dini, dan penyalahgunaan obat terlarang dan zat adiktif (NAPZA). Meskipun pada awalnya fokus mengenai kesehatan reproduksi saja, BKKBN menyadari bahwa permasalahan yang dihadapi remaja sangat kompleks sehingga program GenRe ikut beradaptasi menyesuaikan dengan permasalahan yang banyak timbul dalam kehidupan remaja. Program GenRe berkembang untuk memasarkan informasi dan edukasi yang lebih umum seperti membangun kesadaran remaja bagaimana merencanakan pendidikan, persiapan memasuki dunia pekerjaan, kehidupan pertemanan, dan hal-hal lain yang berkaitan dengan masalah yang dihadapi selama masa transisi remaja.

Menurut Itani dan korda (2015) pemanfaatan media sosial untuk meningkatkan pengetahuan dan perilaku yang lebih sehat menunjukkan hasil yang efektif. Hal ini dapat dilihat dari penelitian Dotulong (2017) yang mengkaji proses pemasaran sosial yang dilakukan oleh TNI. Lembaga Negara ini melakukan pemasaran sosial nilai-nilai mereka melalui media sosial untuk mengonstruksi citra mereka. TNI berupaya mengonstruksi citra sebagai lembaga spesialisasi perang menjadi lembaga yang manunggal dengan rakyat, humanis dan berdedikasi dalam menjalankan berbagai tugas kemanusiaan lainnya. Hasilnya TNI dinilai sebagai lembaga Negara yang paling dipercaya (Dimyati, 2016 dalam Dotulong, 2019). Penelitian lain yang dilakukan Andarini (2015) menunjukkan bahwa organisasi nirlaba AIMI bukan hanya mampu meningkatkan kesadaran masyarakat mengenai pentingnya memberikan ASI kepada anak, tetapi mampu menjadi gerakan nyata yang bersifat nasional untuk saling mendukung dalam proses memberikan ASI kepada anak. Dalam pemasaran sosial yang mereka lakukan, AIMI memanfaatkan media sosial, milis, dan website untuk memasarkan kampanye mereka.

Meskipun media sosial memiliki potensi yang cukup besar sebagai alat untuk promosi dan pendidikan kesehatan, media ini, seperti media promosi kesehatan tradisional, membutuhkan aplikasi yang cermat dan mungkin tidak selalu mencapai hasil yang diinginkan. Berdasarkan paparan konsep mengenai pemasaran sosial, media sosial dari penelitian terdahulu, penulis tertarik untuk mendalami tema bagaimana media sosial digunakan untuk pemasaran sosial, terutama oleh lembaga Negara. Oleh karena itu dalam penelitian ini peneliti mengajukan pertanyaan 1). Bagaimana media sosial digunakan dalam implementasi pemasaran sosial oleh lembaga Negara? dan 2). Bagaimana lembaga negara mengemas pesan di media sosial untuk meningkatkan kesadaran remaja dalam menghadapi masa transisi yang mereka hadapi? Adapun tujuan dari penelitian ini adalah 1). Memberikan gambaran deskriptif implementasi pemasaran sosial di media sosial yang dilakukan oleh lembaga Negara dan 2). Menjelaskan strategi pengemasan pesan di media sosial yang dilakukan oleh lembaga Negara dalam rangka meningkatkan kesadaran remaja dalam menghadapi masa transisi yang mereka hadapi. 


\section{Metode Penelitian}

Penelitian ini menggunakan pendekatan kualitatif yang bersifat deskriptif. Menurut Neuman (2014) penelitian semacam ini fokus untuk membentuk penjelasan yang mendetail dan menggambarkan kondisi tertentu yang muncul dalam realitas kehidupan sosial yang menjadi isu atau masalah yang ingin dibahas oleh peneliti. Dengan menggunakan pendekatan ini, peneliti diharapkan mendapatkan pemahaman mendalam terkait implementasi pemasaran sosial melalui media sosial oleh lembaga negara dalam kampanye program GenRe dan strategi pengemasan pesan di media sosial yang efektif agar mudah diterima remaja. Selanjutnya penelitian ini juga menggunakan metode studi kasus. Menurut Creswell (2014) studi kasus adalah penelitian yang menganalisis secara lebih mendalam bagaimana sebuah kasus atau fenomena terjadi. Dengan fokus pada kampanye GenRe penelitian ini bertujuan menggali informasi yang mendalam untuk mendapatkan gambaran yang komprehensif bagaimana lembaga Negara telah melakukan adaptasi dengan mulai menggunakan media baru yang tengah digemari masyarakat khususnya remaja, yakni media sosial sebagai sarana pemasaran sosial mereka. Selain itu penelitian ini juga fokus untuk memahami strategi pengemasan pesan yang dinilai efektif bagi remaja.

Dalam penelitian studi kasus, ada enam sumber data yang dapat digunakan yaitu dokumen, catatan arsip, wawancara, pengamatan langsung, observasi partisipan dan perangkat fisik (Yin, 2003). Dalam penelitian ini teknik pengumpulan data dilakukan melalui wawancara semi terstruktur sehingga peneliti dapat menggali informasi seputar isu dan permasalahan yang diangkat dengan detail dan komprehensif namun tetap terarah. Selain wawancara, data penelitian ini juga berupa teks dan gambar yang diambil dari media sosial dan website. Data lain yang digunakan adalah literatur baik secara online maupun offline.

Unit respon (informan/narasumber) dalam penelitian ini dipilih berdasarkan teknik purposive sampling yang berarti bahwa mereka harus memiliki kriteria tertentu yang diasumsikan dapat memberikan informasi mengenai penelitian atau disebut sebagai information-rich-cases (Patton, 2002). Informan/narasumber dalam penelitian ini adalah tiga orang informan dengan kriteria orang-orang yang terlibat dalam kampanye program GenRe, baik admin yang mengelola media sosial Genre maupun pejabat BKKBN yang terlibat dalam membuat kebijakan terkait program GenRe.

Tabel 1. Informasi Informan

\begin{tabular}{lll}
\hline No & \multicolumn{1}{c}{ Nama } & \multicolumn{1}{c}{ Keterangan } \\
\hline 1 & Informan A & Kepala Bagian Monitoring dan Evaluasi Direktorat \\
& & Ketahanan Remaja, BKKBN \\
2 & Informan B & Admin Media sosial GenRe \\
3 & Informan C & Admin Media sosial GenRe \\
\hline \multicolumn{2}{l}{ Sumber: Diolah oleh peneliti }
\end{tabular}


Analisis data dalam penelitian kualitatif pada dasarnya dilakukan untuk memberikan makna terhadap data, menafsirkan atau mentransformasikan data ke dalam bentuk narasi yang kemudian mengarah pada temuan yang bernuansa proposisi ilmiah (thesis) yang akhirnya sampai pada keputusan final (Patton, 2002). Teknis analisis data yang digunakan dalam penelitian ini terdiri dari tiga subproses, yaitu reduksi data, penyajian data dan penarikan kesimpulan atau verifikasi (Miles \& Hubberman, 1984 dalam Denzin\&Lincoln, 1994). Dengan model analisis ini, data-data yang diperoleh peneliti dihimpun, diringkas, dan dikelompokkan sehingga menjadi data terseleksi. Selanjutnya peneliti melakukan kategorisasi dan terakhir melakukan verifikasi dan analisis terhadap data dan literatur sehingga dapat mengambil kesimpulan. Kualitas data dalam penelitian kualitatif dinilai berdasarkan otentitas (authenticity) dan kepercayaan (trustworthiness). Untuk memperoleh otentitas, peneliti melakukan wawancara sendiri dan mendokumentasikan wawancara sebelum diolah menjadi data terseleksi. Sementara untuk menjaga kepercayaan, peneliti mencantumkan referensi yang digunakan dalam menyusun penelitian berasal dari sumber yang kredibel seperti buku, jurnal ilmiah serta data resmi dari lembaga terkait.

\section{Hasil Penemuan dan Diskusi}

\section{Implementasi Pemasaran Sosial Kampanye Genre melalui Media Sosial}

Generasi Berencana yang kemudian disingkat GenRe adalah program yang diinisiasi oleh BKKBN sebagai upaya memberikan pendampingan dalam rangka penyiapan kehidupan berkeluarga bagi remaja. Program GenRe mengedepankan pembentukan karakter remaja agar mereka mampu melewati masa transisi yang sedang mereka hadapi. Materi yang disampaikan diantaranya terkait Kesehatan Reproduksi Remaja (KRR), bahaya penyalahgunaan NAPZA, berbagai life skills, strategi penyiapan kehidupan berkeluarga, serta tema-tema lain yang relevan dengan masalah yang dihadapi oleh remaja. Selama ini kampanye disampaikan melaui Pusat Informasi dan Konseling (PIK) Remaja atau Mahasiswa yang dibentuk di lembaga pendidikan maupun dalam komunitas masyarakat seperti karang taruna. Seiring berkembangnya dunia digital, kini kampanye program GenRe juga mulai dilakukan dengan pendekatan yang lebih kekinian yaitu melalui media sosial yang sangat digemari oleh remaja.

Remaja adalah konsumen utama media sosial (Lusk, 2010). Menurut Basat (2010) dalam Ram \& Horsley (2017) media sosial merupakan alat komunikasi yang mengakar dalam kehidupan remaja yang menjadikannya bagian penting dari kehidupan sehari-hari mereka. Popularitas dan ketergantungan media sosial di kalangan remaja ini terus meningkat, yang menjadikan media sosial dapat dianggap sebagai cara yang paling nyaman untuk berkomunikasi dan berinteraksi dengan anak-anak dan remaja. BKKBN telah melihat potensi ini sehingga kampanye program GenRe yang memang ditujukan bagi remaja juga disampaikan melalui media sosial dengan harapan program yang disampaikan dapat lebih diterima oleh remaja. 
Informan 1 mengakui saat ini kampanye sudah tidak bisa hanya dilakukan dengan cara-cara konvensional seperti kegiatan pertemuan yang mengumpulkan remaja atau mengunjungi sekolah satu per satu. Selain remaja yang dijangkau menjadi sangat terbatas, biaya yang dibutuhkan untuk kegiatan kampanye konvensional juga sangat besar. Media digital adalah salah satu jalan keluar yang efektif dari segi jangkauan dan efisien dari segi kebutuhan dana.

"Sekarang kan semua sudah serba online mba, apalagi yang namanya remaja, kayanya tidak bisa lepas dari gadget dan media sosial. Potensial sekali untuk dijadikan alat kampanye, apalagi kalo untuk kampanye genre yang memang sasarannya adalah remaja. Selama ini kan jangkauan kita masih terbatas ke sekolah, lembaga pendidikan tapi ya kan sekolah banyak sekali dan itu belum bisa kita jangkau semua. Dari segi waktu dan dana juga kan kita terbatas. Medsos kita gunakan untuk kampanye agar program kita sampai ke remaja yang belum bisa kita jangkau secara langsung".

Saat ini kampanye GenRe dilakukan melalui empat media sosial paling populer, yaitu Instagram, Facebook, Twitter, dan YouTube dengan nama akun @GenReIndonesia. Jumlah pengikut terbanyak adalah akun Instagram yang mencapai 40.100 pengikut, kemudian YouTube memiliki 12.900 subscriber, Facebook memiliki 2.949 pengikut dan Twitter hanya memiliki 362 pengikut. Dengan memiliki beberapa akun media sosial diharapkan kampanye program dapat menjangkau lebih banyak remaja. Informan B, sebagai salah satu pengelola media sosial@GenReIndonesia melihat bahwa keempat media sosial ini adalah yang paling populer di kalangan remaja dan paling sesuai untuk dijadikan media kampanye program GenRe.

"Saat ini kita ada empat medsos dengan akun @genreindonesia. Ada Youtube, IG, Facebook dan Twitter. Tim pengelola itu ngeliat medsos ini nih yang paling populer dan banyak dipake sama remaja jadi kita bikin akun @ GenReIndonesia disini dulu deh. Yah ada juga kaya Tiktok atau Snapchat tapi kaya ga pas gitu buat buat kampanye kita. Empat ini aja dulu yang kita fokusin. Yah tapi ga tau juga kalo nanti kita mau nambah medsos yang lain".

Selain menggunakan media sosial, media baru yang digunakan untuk kampanye program GenRe adalah website yang dapat diakses melalui www.genreindonesia.com. Website digunakan untuk pemaparan informasi yang lebih komprehensif yang tidak dapat disampaikan di media sosial seperti artikel dan materi-materi yang membutuhkan penjelasan panjang dan menyeluruh. Website GenRe Indonesia juga berafiliasi dengan hipwee. Tautan DokterGenZ yang di tampilkan dalam web genreindonesia akan menggiring khlayak ke web mereka yaitu doktergenz.hipwee.com. Informan A mengakui bahwa website genreindonesia masih memiliki banyak kekurangan sehingga untuk mengatasi hal tersebut BKKBN menjalin kerjasama dengan doktergenz. Informasi yang ditampilkan di doktergenz juga dinilai selaras dengan nilai dan tujuan yang dikampanyekan oleh program GenRe. 
Resti Sri Elwani, Firman Kurniawan: Pemanfaatan Media Sosial Dalam Pemasaran Sosial Bagi Remaja

“.... Kalo bisa semua yang serba online dan digital akan kita manfaatkan untuk kampanye GenRe. makanya selain medsos kita juga kan punya website genreindonesia, dan aplikasi yang sudah tersedia di playstore .... Websitenya memang masih banyak kekurangan jadi kita kerjasama dengan DokterGenZ. Sambil jalan kita perbaiki sumberdaya milik sendiri kita kolab sama pihak lain yang punya visi dan nilai yang sama dengan GenRe”.

\section{Strategi Pesan Kampanye GenRe di Media Sosial}

Konten yang diunggah oleh semua akun media sosial @genreindonesia adalah berupa foto dan video yang disertai caption. Berdasarkan informan B ada dua kategori konten, yaitu substansi program dan nonsubstansi. Substansi program ini adalah konten yang berkaitan dengan informasi mengenai kesehatan reproduksi remaja, bahaya nikah dini, bahaya narkoba, pentingnya pendidikan, dan hal-hal lain yang bersifat informatif dan menambah wawasan remaja. Sementara konten nonsubstansi adalah konten yang lebih umum seperti dokumentasi kegiatan yang dilakukan oleh GenRe, quote yang memotivasi dan ucapan perayaan hari-hari besar.

"Konten itu kita bagi dua, ada substantive dan nonsubstantif. Kalo substantive itu konten kampanye genre kaya kesehatan reproduksi remaja, bahaya nikah dini, bahaya narkoba, pentingnya pendidikan kaya gitu. Kalo nonsubstantif itu ya kaya dokumentasi kegiatan, quote-quote motivasi dan quote lucu. Atau kalo ada peringatan hari besar ya kita ucapin juga sih..."

Dari dua kategori konten tersebut, menurut informan $\mathrm{C}$, tingkat engagement paling tinggi justru masih dimiliki konten nonsubstansi program. Tujuan awal penggunaan media sosial oleh program GenRe adalah untuk menjangkau remaja yang belum terpapar program GenRe secara langsung. Namun begitu konten non substansi, seperti dokumentasi kegiatan yang dilakukan juga sangat penting untuk kita unggah. Informan A menambahkan ada beberapa alasan kenapa konten nonsubstansi sangat penting untuk tetap diunggah di akun media sosial @genreindonesia, pertama sebagai alat promosi kegiatan bagi remaja yang belum tergabung Pusat Informasi dan Konseling (PIK) di sekolah atau kampus yang menjadi wadah kampanye program GenRe. Setelah melihat berbagai kegiatan yang menarik diharapkan lebih banyak remaja yang bergabung dengan PIK tersebut. Alasan lain konten nonsubstansi penting adalah agar follower tidak jenuh dan melihat bahwa akun ini relevan dengan realitas di sekeliling mereka.

"Kalo kita posting yang substansi sebenarnya lumayan juga yang like dan komen, malah suka banyak yang nanya-nanya.. tapi konten yang paling banyak like dan komen itu rata-rata masih yang non substansi sih. Seperti dokumentasi kegiatan yang dilakukan di PIK atau kompetisi duta GenRe dan adu JAK. Tapi konten nonsubstantif itu penting juga. Karena kalo substansi terus, nanti follower bosen. Konten nonsubstantif itu biar follower jadi merasa deket sama kita juga sih".

Informasi yang disampaikan dalam konten maupun caption yang mengiringinya umumnya singkat dan padat. Hal ini mengingat karakter di media sosial dibatasi sehingga untuk penjelasan yang lebih komprehensif pengelola 
memberikan tautan ke web genreindonesia.com atau doktergenz yang sudah bekerja sama dengan BKKBN. Informan B menyatakan baik caption maupun konten biasanya dikemas agar follower penasaran dan tertarik untuk membuka website agar mendapatkan penjelasan yang lebih komprehensif.

"postingan dan caption di medsos itu biasanya kan singkat-singkat aja. Kadang kata-katanya atau gambarnya yang kita create biar follower itu penasaran dan mau klik web yang kita sebutin, bisa ke web kita sendiri genreindonesia.com atau ke web nya doktergenz".

Kreatifitas penyampaian pesan adalah kunci keberhasilan dalam menarik perhatian khalayak sasaran, baik yang sudah menjadi follower terlebih lagi bagi khalayak yang belum menjadi follower. Untuk menarik perhatian khalayak, konten yang diunggah di akun media sosial GenRe Indonesia banyak menggunakan animasi.

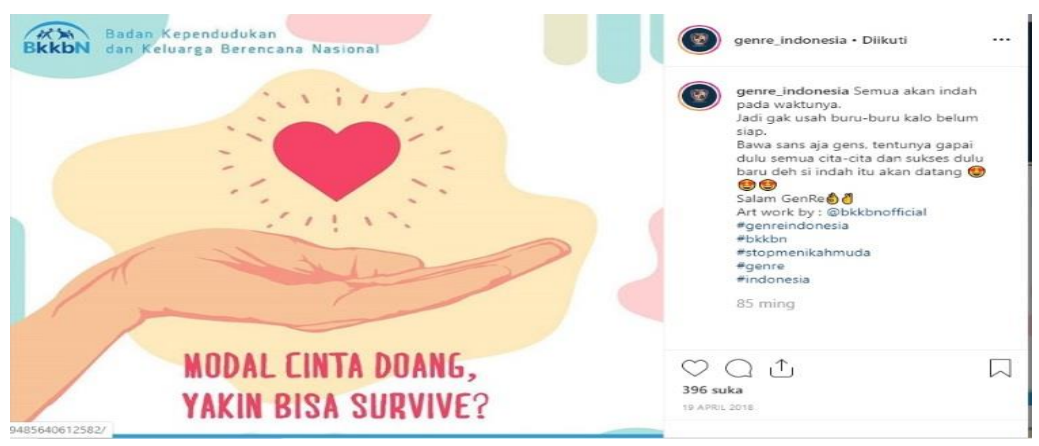

Gambar 1: Contoh postingan akun @genreindonesia (Sumber: akun instgaram @genreindonesia)

Menurut informan B penggunaan animasi ini selain menarik perhatian remaja juga memberikan kesan yang lebih fun dan sesuai dengan selera remaja. Berdasarkan hal itu, baik konten substantif maupun nonsubstantif mayoritas diunggah dalam bentuk animasi.

"Karena sasaran kita dan follower juga memang remaja semua, kayanya gambar animasi cocok nih karena keliatan eye catching dan feed kita juga jadi ga borring. Kalo udah eyecatching kan harapan kita follower mau baca informasi yang kita sampaikan."

Frekuensi mengunggah konten adalah salah satu kunci keberhasilan pemasaran dalam media sosial. Informan B menegaskan admin pengelola media sosial @genreindonesia berusaha untuk mengunggah konten setiap hari. Meskipun hal ini cukup menantang mengingat tim yang sangat terbatas, tetapi mereka menyadari bahwa frekuensi mengunggah konten adalah salah satu strategi untuk menjaga komunikasi GenRe dengan khalayak. Semakin sering khalayak terpapar dengan informasi diharapkan pengetahuan khalayak tentang program GenRe juga semakin bertambah. 
Resti Sri Elwani, Firman Kurniawan: Pemanfaatan Media Sosial Dalam Pemasaran Sosial Bagi Remaja

"Kita usahain banget sih untuk update tiap hari, karena kan semakin banyak dan semakin sering kita menyampaikan konten informasi, remaja jadi semakin tahu kan tentang program kita. Masalahnya konten substansi lumayan susah sih kan ga bisa kita buat sembarangan, kita harus mastiin kebenarannya gimana, nanti informasi yang kita sampaikan kontroversial apa nggak. Jadi yang sering kita upload masih konten nonsubstansi”.

\section{Implementasi Pemasaran Sosial Program Generasi Berencana (GenRe) dalam Media Sosial}

Menurut Kotler dan Roberto (1989) ada lima elemen dalam kampanye perubahan sosial, yaitu cause, change agent, target adopters, channels, dan change strategy. Minimnya informasi dan kesadaran remaja mengenai masa transisi yang akan dihadapi remaja adalah salah satu penyebab remaja tidak mampu melewati masa transisi tersebut dan akibatnya adalah mereka terjerumus ke dalam hal negatif (cause). Program Generasi Berencana yang disingkat menjadi GenRe (change agent) adalah salah satu upaya pemerintah melalui salah satu lembaga Negara, yaitu BKKBN berusaha mengedukasi remaja (target adopters) dan meningkatan kesadaran mereka bagaimana melewati masa-masa kritis ini.

Selama ini kampanye secara langsung maupun melalui media konvensional baik elektronik dan cetak (channels) telah konsisten dilakukan. Namun cara-cara tersebut masih memiliki kekurangan mengingat jumlah remaja yang harus dijangkau sangat banyak sementara waktu dan dana juga sangat terbatas. Dengan mengintegrasikan media baru seperti web dan media sosial diharapkan pemasaran sosial Program GenRe dapat berjalan lebih efektif dan efisien. Hal ini sejalan dengan teori dalam penelitian yang dilakukan dalam beberapa implementasi pemasaran sosial yang menyebutkan dengan menggabungkan media sosial, even khusus, dan media konvensional terbukti dapat meningkatkan kesadaran khalayak (Luca \& Suggs, 2019)

Penggunaan media sosial sebagaimana karateristik yang dimilikinya memberikan kesempatan kepada khalayak, dalam hal ini follower untuk berinteraksi diantara sesama penggunanya. Pertukaran ide dan opini dalam dialog ini dapat menjadi titik awal untuk menciptakan koneksi yang lebih dalam dan hubungan jangka panjang diantara follower dan program GenRe. Hubungan baik diantara pihak-pihak yang berkomunikasi dalam media sosial ini dapat mendorong follower untuk menjadi perpanjangan tangan dan pendukung utama aktifitas pemasaran sosial itu sendiri bahkan hingga mendorong terjadinya perubahan sosial (Thackeray, Neiger, \& Keller, 2012).

Meskipun awalnya digunakan sebagai sarana berkespresi dan sosialisasi (Herring, 2015), temuan baru membuktikan bahwa media sosial juga digunakan untuk mencari informasi oleh remaja. Misalnya wikipedia yang telah lebih dulu dikenal sebagai platform media sosial yang sering digunakan sebagai titik awal dalam mencari informasi. Namun semakin kesini, media sosial lain seperti YouTube dan Twitter juga mulai digunakan sebagai sumber berita oleh remaja (Kim, St, Wi, Ching, \& Sin, 2012). Menurut Krumsvik (2018) dalam beberapa tahun terakhir, media sosial menjadi distributor berita terbesar bahkan menjadi ruang kunci membagikan berita, terutama bagi kaum muda (Indrajaya \& 
Lukitawati, 2019). Hal ini menguatkan alasan pemilihan media sosial sebagai salah satu strategi pemasaran sosial program GenRe dirasa sudah tepat, karena media ini adalah media yang sangat diperhatikan dan sangat dekat dengan remaja.

Tidak hanya media sosial, pemasaran sosial program GenRe juga dilakukan dengan berbagai bentuk media baru lainnya seperti website dan aplikasi. Implikasi dari pengunaan omnichanel seperti ini lazim terjadi dalam pemasaran konvensional. Setiap media memiliki karakteristik tertentu sehingga diindikasikan berhasil menjangkau publik dan lingkungan yang berbeda-beda juga (Luca \& Suggs, 2019). Jika media sosial hanya menampilkan info yang singkat dan padat maka tautan ke web dapat mendorong khalayak untuk mengakses informasi dan penjelasan yang lebih komprehensif. Strategi komunikasi menggunakan omnichanel seperti ini memungkinkan khalayak, terutama follower untuk mendapatkan informasi awal melalui media sosial dan penjelasan detil dapat terpenuhi melalui web yang menyajikan penjelasan yang lebih panjang dan menyeluruh (Payne, Barger, \& Peitier, 2017).

\section{Strategi Penyampaian Pesan Pemasaran Sosial di Media Sosial}

Pengelola akun media sosial @genreindonesia membagi konten yang diunggah dalam dua kategori yaitu konten substansi dan nonsubstansi. Konten substansi adalah konten yang berisi tentang program GenRe yang sifatnya edukatif dan informatif. Misalnya konten mengenai kesehatan reproduksi, pentingnya mempersiapkan pernikahan, menghindari nikah di usia terlalu dini, bahaya narkoba dan hubungan seksual pranikah dan materi-materi lain yang terkait dengan hal-hal yang berkaitan dengan masalah yang dihadapi remaja. Konten substansi ini bertujuan untuk menambah wawasan dan kesadaran remaja dalam menghadapi masalah yang mereka hadapi di masa transisi. Konten ini dapat dikatakan sebagai tujuan utama program GenRe yaitu mendampingi dan mengedukasi remaja dalam mengahadapi masa transisi yang mereka hadapi. Sementara konten nonsubstansi adalah konten yang sifatnya lebih umum, misalnya dokumentasi kegiatan, pengumuman kegiatan yang dilakukan oleh program GenRe, dan quote motivasi. Meskipun tidak berkaitan langsung dengan tujuan Program GenRe, namun konten semacam ini tetap penting agar akun @ genreindonesia tetap relevan dengan follower.

Dari hasil wawancara dengan pengelola akun media sosial @ genreindonesia dan dari hasil pengamatan peneliti, konten nonsubstansi masih memiliki engagement lebih tinggi jika dibanding dengan konten substansi. Hal ini patut menjadi perhatian, mengingat jika kembali kepada tujuan utamanya program GenRe bertujuan memberikan edukasi kepada remaja bagaimana menghadapi masalah yang mereka hadapi dalam masa transisi. Rendahnya engagement konten substansi dikhawatirkan mengakibatkan materi dan infromasi yang diunggah dalam media sosial @genreindonesia pada akhirnya tidak sampai kepada remaja. Dampak terburuknya tentu saja tujuan untuk meningkatkan kesadaran remaja tidak akan tercapai.

Kreatifitas dalam menyampaikan pesan di media sosial sudah dilakukan oleh pengelola akun @genreindonesia, diantaranya adalah mengunggah konten dalam gambar animasi. Pemilihan gambar-gambar bertema animasi ini sudah 
tepat mengingat target adopter program GenRe adalah remaja. Visual dengan karakter animasi ini adalah salah satu faktor yang sangat mempengaruhi dalam proses pemasaran bagi remaja karena dianggap memiliki unsur menyenangkan (fun appeal) bagi mereka (Truman \& Elliot, 2019). Namun sayangnya, menurut pengamatan peneliti frekuensi unggahan konten substansi ini masih jarang jika dibanding dengan unggahan konten nonsubstansi. Untuk mencapai tujuan yang telah ditentukan, menjaga konsistensi dan frekuensi dalam mengunggah konten sangat penting dalam pemasaran sosial di media sosial (Dotulong, 2019). Tidak konsisten dan kurangnya frekuensi dalam mengunggah konten akan membingungkan follower bahkan cenderung akan membuat mereka lupa dengan keberadaan akun media sosial kita (Patel, 2016).

Salah satu strategi pengemasan pesan lain yang dapat dikembangkan untuk meningkatkan engagement adalah menggunakan pihak ketiga. Strategi menggunakan pihak ketiga ini sudah lazim dalam pemasaran konvensional dan menjadi salah satu ciri pemasaran dalam media sosial. Pihak ketiga ini dikenal dengan istilah digital influencer. Digital influencer adalah pihak ketiga yang independent yang memiliki kemampuan membentuk sikap khalayak melalui blog, tweet dan media sosial lainnya (Freberg, Freberg, \& Mcgaughey, 2011). Sederhananya influencer adalah individu yang bukan berasal dari kalangan artis atau public figure tetapi memiliki popularitas cukup tinggi karena memiliki banyak follower. Potensi inilah yang dinilai peneliti belum dimanfaatkan oleh Program GenRe.

Dalam strategi distribusi pesan program GenRe di media sosial ini, influencer menjadi lapisan kedua (second layer) yang bermanfaat untuk membantu tim dalam mengelola media sosial (Dotulong, 2019). Dengan adanya second layer, pengelola akun media sosial tidak terjebak dalam kebingungan ingin mengemas narasi pesan seperti apa. Second layer ini yang bertugas mengemas narasi dari pengelola GenRe menjadi narasi yang sesuai dengan kelompok yang dirinya wakilkan (Dotulong, 2019). Pelibatan influencer sebagai second layer dalam mendistribusikan pesan dapat membuat informasi yang disampaikan lebih mudah diterima. Selain itu proses pengemasan pesan tidak perlu dilakukan sendiri oleh pengelola akun @genreindonesia karena influencer sudah memiliki strategi sendiri bagaimana mengemas informasi dan materi yang bisa jadi cukup berat untuk difahami target adopter menjadi konten yang lebih mudah diterima. Tujuan ahirnya tentu saja materi dan informasi yang disampaikan Program GenRe dapat menambah informasi dan meningkatkan kesadaran remaja dalam menghadapai masa transisi yang mereka hadapi.

Berdasarkan hasil analisis maka diperoleh model implementasi pemasaran sosial melalui media sosial bagi remaja yang dilakukan pengelola Program GenRe. Dengan menambahkan rekomendasi bagi pengelola akun media sosial untuk memanfaatkan influencer dalam mendistribusikan pesan. 


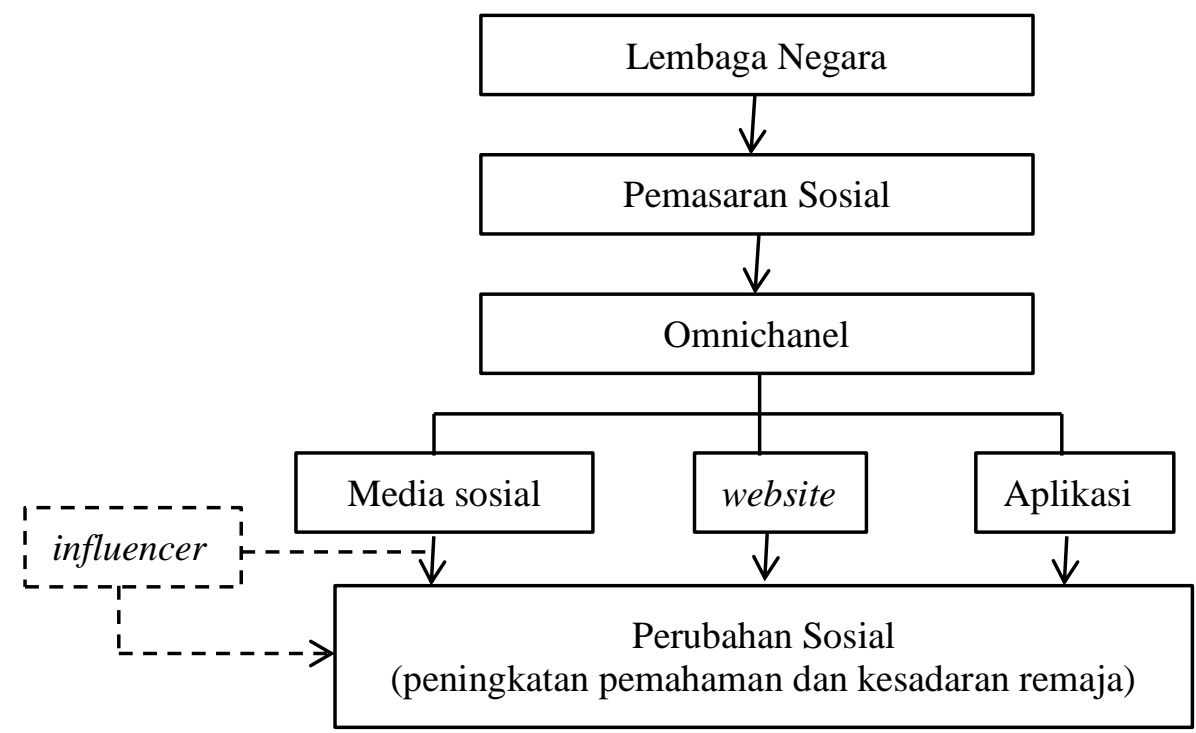

\section{Simpulan}

Sebagai salah satu upaya membantu meningkatkan kesadaran remaja menghadapi masa transisi yang mereka hadapi, BKKBN melakukan pemasaran sosial program Generasi Berencana (GenRe) melalui media sosial. Media baru ini digunakan sebagai salah satu strategi untuk mendekatkan program ini kepada remaja karena media ini adalah media yang sangat sangat lekat dengan keseharian remaja. Namun begitu, pemasaran sosial program GenRe juga dilakukan dengan berbagai bentuk media baru lainnya seperti website dan aplikasi. Penggunaan omnichanel dalam proses pemasaran seperti ini, bertujuan untuk menjangkau publik dan memberikan efek yang berbeda karena setiap media memiliki karakteristik tertentu yang dapat menjangkau publik dan lingkungan yang berbeda-beda juga. Strategi penyampaian pesan program GenRe di media sosial dilakukan dengan mengunggah konten dengan gambar animasi yang dianggap dapat menarik perhatian dan sesuai dengan selera remaja. Strategi lain yang dilakukan adalah berusaha untuk tetap menjaga relevansi dengan realitas kehidupan remaja dengan mengunggah konten-konten yang tidak melulu berisi materi dan substansi program seperti kata-kata motivasi dan ucapan selamat ketika ada hari-hari besar.

Penelitian mengenai penggunaan media sosial untuk pemasan sosial masih terbatas. Terutama jika dibandingkan dengan pemanfaatan media sosial untuk pemasaran konvensional atau pemasaran bidang politik (Bresciani \& Schmeil, 2013; Korda, 2015). Penelitian mengenai pemanfaatan media sosial untuk pemasaran sosial bagi remaja ini terbatas hanya pada tataran peningkatan pengetahuan khalayak (objective knowledge). Peneliti merekomendasikan penelitian lebih lanjut yang mengukur dampak pemasaran sosial yang dilakukan melalui media sosial apakah dapat merubah perilaku khalayak (behaviour objectives). Selain itu peneliti juga merekomendasikan agar pengelola akun @genreindonesia sebaiknya lebih fokus untuk mengunggah konten substansi mengingat engagement konten substansi masih lebih rendah jika dibanding 
Resti Sri Elwani, Firman Kurniawan: Pemanfaatan Media Sosial Dalam Pemasaran Sosial Bagi Remaja

nonsubstansi. Hal ini disebabkan pengelola akun program GenRe tidak memperhatikan konsistensi dan frekuensi dalam mengunggah konten substansi. Selain itu, pelibatan pihak ketiga untuk meningkatkan engagement juga belum dimanfaatkan. Padahal, penggunaan digital influencer adalah ciri pemasaran media sosial. Mereka dapat menjadi lapisan kedua (second layer) yang bertugas mengemas narasi program GenRe sesuai dengan ciri khas mereka masing-masing. Dengan begitu informasi dan materi dapat lebih mudah diterima dan difahami oleh khalayak, khususnya oleh remaja.

\section{Ucapan Terima Kasih}

Peneliti mengucapkan terima kasih kepada narasumber yang bersedia meluangkan waktu dan berbagi informasi, kepada tim dari Jurnal Komunikasi UNTAR serta seluruh pihak yang terlibat baik secara langsung maupun tidak langsung dalam proses pengumpulan dan pengolahan data hingga proses penulisan artikel ini selesai.

\section{Daftar Pustaka}

American Psychological Assosiation. (2002). A Reference for Professional: Developing Adolescents. New York. American Psychological Assosiation

Andarini, S. S. (2015). Pemasaran Sosial melalui Media Sosial oleh Organisasi Nirlaba (Studi Kasus: Social Media Marketing dan Model Adopsi Produk Sosial di Media Sosial dalam Kampanye ASI oleh Asosiasi Ibu Menyusui Indonesia). Tesis. FISIP UI

Asosiasi Penyelenggara Jasa Internet Indonesia. (2018). Penetrasi \& Perilaku Pengguna Internet Indonesia - Survey 2017. Jakarta

Ayu, S. M., \& Kurniawati, T. (2017). Hubungan Tingkat Pengetahuan Remaja Putri tentang Aborsi dengan Sikap Remaja Terhadap Aborsi di MAN 2 Kediri Jawa Timur. Unnes Journal of Public Health, 6(2), 2-5.

BKKBN. (2017). Survei Demografi dan Kesehatan Indonesia. BKKBN: Jakarta BPS. (2018). Survey Sosial Ekonomi Nasional. BPS: Jakarta

Bresciani, S., \& Schmeil, A. (2013). Social Media Platforms for Social Good. 2012 6th IEEE International Conference on Digital Ecosystems and Technologies (DEST), 1-6. https://doi.org/10.1109/DEST.2012.6227944

Creswell, J.W. (2014). Research Methods: QUalittaive and Quantitative: Mixed Methods Approach. Thousand Oaks: SAGE

Dahl, S., \& N. (2010). Current Themes in Social Marketing Research: Textmining the past five years.

Denzin, N. K. \& Lincoln, Y. S. (1994). Handbook of Qualittaive Research. London : SAGE

Dotulong, C. M. (2019). Pemasaran Sosial Nilai Lembaga Negara melalui Media Sosial. Studi Kasus Media Sosial Lembaga Negara Bidang Pertahanan dan Keamanan.Tesis. FISIP-UI

Freberg, K., Freberg, L., \& Mcgaughey, K. (2011). Who are the social media influencers? A study of public perceptions of personality. Public Relations 
Review, (October 2017), 9-12. https://doi.org/10.1016/j.pubrev.2010.11.001

French, J. (2012). An Introduction to the Key Pinciples and Concepts of Social Marketing, 1-27.

Herring, S. C. (2015). Teens, Gender, and Self-Presentation in Social Media.

Hurlock, A. B. (1998). Perkembangan Anak Jilid I. Jakarta: Erlangga

Indrajaya, S. E., dan Lukitawati, L. (2019). Tingkat Kepercayaan Generasi Z terhadap Berita Infografis dan Berita Ringkas di Media Sosial. Jurnal Komunikasi, 11(2), pp. 169-182. https://journal.untar.ac.id/index.php/komunikasi/article/view/5045

Kaplan, A. M., \& Haenlein, M. (2010). Users of the world, unite! The challenges and opportunities of Social Media. https://doi.org/10.1016/j.bushor.2009.09.003

Kemenkes. (2014). Info Datin Reproduksi Remaja.2015. Kemenkes: Jakarta

Kent, M. L., \& Taylor, M. (1998). Building Dialogic Relationships through The World Wide Web. Public Relations Review, 24(3), 321-334.

Kim, K. S., St, N. P., Wi, M., Ching, S., \& Sin, J. (2012). Use of social media in different contexts of information seeking: effects of sex and problem solving style.

Korda, H., \& Itani, Z. (2015). Harnessing Social Media for Health Promotion and Behavior Change, (September). https://doi.org/10.1177/1524839911405850

Kotler, P., \& Roberto, E. L. (1989). Social Marketing: Strategies for Changing Public Behavior. The Free Press.

Kusumasari, D., \& Arifianto, S. (2019). Makna Teks Ujaran Kebencian Pada Media Sosial,(9),1-15. https://journal.untar.ac.id/index.php/komunikasi/article/view/ 4045

Luca, N. R., \& Suggs, L. S. (2019). Strategies for the Social Marketing Mix : A Systematic Review This article, (May). https://doi.org/10.1080/15245004.2010.522767

Lusk, B. (2010). Digital Natives and Social Media Behaviors: An Overview: Prevention Researcher.doi:10.1037/e510232011-001

Nakhaee, S., Vagharseyyedin, S. A., Afkar, E., \& Mood, M. S. (2017). The Relationship of Family Communication Pattern with Adolescents ' Assertiveness, 14(4). https://doi.org/10.5812/modernc.66696.Research

Neuman, W.L. (2014) Social Research Methods: Qualitative and Quantitative Approaches. $7^{\text {th }}$ edition. Essex: Pearson

Nurhayati. (2011). Hubungan Pola Komunikasi dan Kekuatan Keluarga dengan Perilaku Seksual Beresiko pada Remaja di Desa Tridaya Sakti Kecamatan Tambun Selatan Kabupaten Bekasi. Tesis.

Patel, Neil. (2016). How Frequently You Should Post on Social Media According to The Pros. Forbes.com

Patton, M. Q. (2002). Qualitative Evaluation and Research Methods. Thousand Oaks: SAGE

Payne, E. M., Barger, V. A., \& Peitier, J. W. (2017). Omni-channel marketing , integrated marketing communications and consumer engagement: A 
research agenda Omni-channel marketing, integrated marketing communications, and consumer engagement: A research agenda $\dagger$, (June). https://doi.org/10.1108/JRIM-08-2016-0091

Ram, A., \& Horsley, J. S. (2017). The role of social media on positive youth development_An analysis of 4-H Facebook page and 4-H'ers' positive development. Children and Youth Services Review, 77(January), 127-138. https://doi.org/10.1016/j.childyouth.2017.04.014

Salam, R. A., Sc, M., Faqqah, A., D, M., Sajjad, N., S, M. B. B., ... Ph, D. (2016). Improving Adolescent Sexual and Reproductive Health: A Systematic $\begin{array}{llll}\text { Review of } & \text { Potential }\end{array}$ https://doi.org/10.1016/j.jadohealth.2016.05.022

Thackeray, R., Neiger, B. L., \& Keller, H. (2012). Health Promotion Practice. https://doi.org/10.1177/1524839911432009

Truman, E., Elliott, C.(2019). Identifying food marketing to teenagers: a scoping review. Int J Behav Nutr Phys Act 16. doi:10.1186/s12966-019-0833-2

We Are Social. (2019). Digital 2019-Indonesia. Retrieved from https://wearesocial.com/global-digital-report-2019

WHO. (2014). Adolescent Pregnancy. Fact Sheet. Retrieved from https://apps.who.int/iris/bitstream/handle/10665/112320/WHO_RHR_14.0 8_eng.pdf

WHO. (2020) Adolescent Pregnancy. Fact Sheet. Retrieved from https://www.who.int/news-room/fact-sheet/detail/adolescent-pregnancy

Yin, R. K. (2003). Case study research: Design and methods (3rd ed.). Thousand Oaks, CA: Sage. 